\title{
Chemical and microbiological characteristics of sugar cane silages treated with microbial inoculants ${ }^{1}$
}

\section{Carla Luiza da Silva Ávila ${ }^{2}$, Alexandre Rocha Valeriano ${ }^{3}$, José Cardoso Pinto ${ }^{4}$, Henrique César Pereira Figueiredo ${ }^{5}$, Adauton Vilela de Rezende ${ }^{6}$, Rosane Freitas Schwan ${ }^{7}$}

\author{
1 Projeto financiado pelo CNPq. \\ 2 Pós-Doutorado em Zootecnia - UFLA. \\ 3 Programa de Pós-graduação em Zootecnia - UFLA. \\ ${ }^{4}$ Departamento de Zootecnia - UFLA. \\ ${ }^{5}$ Departamento de Medicina Veterinária - UFLA. \\ ${ }^{6}$ Departamento de Zootecnia - UNIFENAS. \\ 7 Departamento de Biologia - UFLA.
}

\begin{abstract}
The aim of this research was to evaluate the effect of microbial additives containing heterofermentative or homofermentative bacteria on the chemical and microbiological characteristics of sugar cane (Saccharum spp) silages. Sugar cane was inoculated with Lactobacillus plantarum, L. paracasei, L. brevis or L. buchneri previously isolated from sugar cane silages or commercial inoculants containing L. buchneri or L. plantarum. Silages were produced in laboratory silos $(10 \times 60 \mathrm{~cm}$ PVC tubes) and evaluated 90 days after ensiling. A randomized complete design was used with eight treatments (seven inoculants and control - without inoculant) and three replications. The inoculation with bacteria affected lactic acid bacteria, yeast populations, volatile fatty acids and ethanol contents in the silages. Inoculation with different strains of the same species of bacteria result in silages with different chemical and microbiological characteristics. Two of the L. buchneri strains show the best results in relation to silage quality.
\end{abstract}

Key Words: acetic acid, ethanol, heterofermentative bacteria, lactic acid, Lactobacillus, yeasts

\section{Características químicas e microbiológicas de silagens de cana-de-açúcar tratada com inoculantes microbianos}

\begin{abstract}
RESUMO - Objetivou-se avaliar o efeito de aditivos microbianos contendo bactérias heterofermentativas ou homofermentativas sobre as características químicas e microbiológicas de silagens de cana-de-açúcar (Saccharum spp.). A canade-açúcar foi inoculada com Lactobacillus plantarum, L. paracasei, L. brevis ou L. buchneri, previamente isolados de silagens de cana-de-açúcar, ou inoculantes comerciais contendo L. buchneri ou L. plantarum. As silagens foram produzidas em silos laboratoriais (tubos de PVC $-10 \times 60 \mathrm{~cm}$ ) e avaliadas 90 dias após a ensilagem. O delineamento utilizado foi o inteiramente casualizado com oito tratamentos (sete inoculantes e um controle, sem inoculante) e três repetições. A inoculação influenciou as populações de bactérias ácido-láticas e leveduras e também as concentrações de ácidos graxos voláteis, ácido lático e etanol nas silagens. A inoculação com cepas diferentes da mesma espécie de bactéria resulta em silagens com características químicas e microbiológicas diferentes. Duas cepas de L. buchneri promovem melhores resultados de qualidade das silagens.
\end{abstract}

Palavras-chave: ácido acético, ácido lático, bactérias heterofermentativas, etanol, Lactobacillus, leveduras

\section{Introduction}

Sugar cane (Saccharum spp.) is a fodder plant often used by dairy farmers, mainly because of its high production of forage per unit area (80 to $150 \mathrm{t} / \mathrm{ha}$ ), low production cost per ton of dry matter (DM) and good nutritional value when corrected in the protein and minerals content (Silva, 1993). Sugar cane ensilage has become increasingly appealing to producers because it makes the sugar cane plantation management easier and produces preserved feed for livestock. However, silages normally present intense alcoholic fermentations by yeasts, with a high rate of DM loss, accumulation of cell wall components and reduction in the forage digestibility (Ferreira et al., 2007). Furthermore, sugar cane silages present a high rate of residual sugar and lactic and acetic acid, which are potentially usable substrates for spoilage microorganisms that spoil the silage after opening the silos (McDonald et al., 1991).

The bacteria which produce lactic acid have been extensively evaluated as inoculants in silages in order to 
increase the number and the competitivity of these microorganisms in the ensiled mass, increasing the production of lactic acid and inhibiting the growth of undesirable microorganisms. Recently, greater attention has been given to the addition of heterolactic bacteria, especially of the Lactobacillus buchneri species, which have shown promising results mainly in the inhibition of the fungi growth and in the increase of the aerobic stability in the silagens (Filya, 2003). These results motivated researchers to evaluate the addition of these microorganisms to sugar cane silage with the objective of inhibiting yeast growth and reducing alcoholic fermentation (Pedroso et al., 2005).

According to Muck \& Kung Jr. (1997), one of the determining factors for successful application of microbial inoculants in silages is the compatibility between the forage plant which is being ensiled and the used microorganisms. Ávila et al.(2009) studied the microbial profile of sugar cane silages and observed that the homofermentative strains of $L$. plantarum and $L$. paracasei species and the heterofermentative strains of $L$. brevis species grew with a higher frequency during the whole process. Based on these data, the objective of this study was to evaluate the effect of microbial inoculants containing heterofermentative bacteria, isolated from sugar cane silages or contained in comercial products, on the microbiological and chemical characteristics of sugar cane silages.

\section{Material and Methods}

The experiment was carried out in the Departamentos de Zootecnia e Biologia of the Universidade Federal de Lavras (UFLA), in Lavras, Minas Gerais. The sugar cane, from a sugar cane farm established four years ago on land belonging to UFLA, was collected with regrowth age of about 12 months, in the dry season (July), when it presented $18^{\circ}$ brix. After manual collection, the cane was chopped in a stationary chopper, without straw extraction, to 10 to 30 $\mathrm{mm}$ particles for silage production.

Of the seven evaluated bacterial inoculants, four were prepared in the Laboratório de Microbiologia of the Departamento de Biologia of UFLA, from sugar cane silage strains isolated by Ávila et al. (2009). The other evaluated bacterial strains, present in the commercial inoculants, were the L. buchneri strain found in the Pioneer 11A44TM product; L. buchneri strain NCIMB 40788, found in the Lalsil Cana product, and the L. plantarum strain, found in the Biomax ${ }^{\circledR}$ product. Although the inoculants showed different populations of active bacteria per gram of product, all were applied to obtain populations of $10^{5} \mathrm{cfu}$ bacteria/g forage at ensiling.

The eight used treatmens were: silage without inoculant (control) and silages inoculated with the L. plantarum strain UFLA-1-SIL (LP), L. paracasei strain UFLA-67-SIL (LPARA), L. brevis strain UFLA-65-SIL (LBREVIS), L. buchneri strain UFLA-72-SIL (LB), L. buchneri of the Pioneer 11A44TM (LBP) inoculant, L. plantarum of the Biomax $5^{\circledR}$ (LPB) inoculant and L. buchneri of the SiloMax Lalsil Cana ${ }^{\circledR}$ (LBLC) inoculant.

The chopped forage was ensiled in PVC $(10 \times 60 \mathrm{~cm})$ silos fitted with Bunsen type valves for the gas escape. The inoculants were applied to the forage at ensiling, using manual sprinklers (one for each treatment). Each parcel of the treatmens received $80 \mathrm{~mL}$ bacterial suspension. For the control silage, the forage was sprinkled with $80 \mathrm{~mL}$ sterile water. After adding the inoculants and homogenizing the foragem, samples were taken for chemical and microbiologial analyses. The forage (2 to $3 \mathrm{~kg}$ ) was manually compacted in the silos with the aid of an iron bar, aiming to obtain a compaction density of aproximately $600 \mathrm{~kg}$ forage per $\mathrm{m}^{3}$. The silos were stored at ambient temperature, protected from daylight and rain. Ninety days after ensiling, three samples were taken from each silo, discarding the extremities of the silage (aproximately $10 \mathrm{~cm}$ ). The samples which were destined for the determination of volatile fatty acids, lactic acid and ethanol were put in plastic bags and frozen at $-5^{\circ} \mathrm{C}$ and those which were destined for the microbiological analysis were immediately forwarded to the Microbiology Laboratory, where the $\mathrm{pH}$ was measured by means of a potentiometer.

For the bromatological analysis of the fresh forage and silages, samples were taken in a fan-assisted oven at $65^{\circ} \mathrm{C}$, ground in Willey type mill with shieve mesh 30 and forwarded to the laboratory to determine the dry matter (DM) and crude protein (CP) contents, according to the recommended methods by AOAC (1990), and the neutral detergent fiber (NDF), and acid detergent fiber (ADF) contents, according to techniques described by Silva (1990). To determine the concentrations of volatile fatty acids, lactic acid and ethanol, the samples were frozen to extract the juice with a hydraulic press. The juices were acidified with metaphosphoric acid at $25 \%$ and forwarded for analysis by gaseous cromatography (AOAC, 1980).

In the microbiological analyses of the fresh forage and silages, extracts were prepared by agitating $80 \mathrm{~g}$ forage (Excella E25 agitator E25, New Brunswick Scientific, Edison, New Jersey, USA) in $720 \mathrm{~mL}$ peptone sterile water (1\% peptone) for 20 minutes. Decimal dilutions of $10^{-1}$ to $10^{-6}$ were prepared from these extracts for the microbiological 
counting. The lactic acid bacteria (LAB) were counted in MRS (Man Rogosa Sharpe, Difco) mean with nystatin (EMS) at $0.4 \%$ yeasts; in YEPD [ $0.3 \%$ yeast extract (Merck); 0.3\% malt extract (Merck); 0.5\% peptone (Himedia); 1.0\% glucose (Merck) and 2.0\% AGAR (Merck) per litre, containing $100 \mathrm{mg}$ chloramphenicol (Sigma, St. Louis, USA); $\mathrm{pH}$ 3.5] and filamentous fungi (FILFU) in Agar in Dicloran Bengal Rose Rosa Bengala chloramphenicol (DRBC) agar, by the technique of surface plating. The Petri dishes were incubated at $28^{\circ} \mathrm{C}$ and the count was performed manually after the specific time of incubation for the growth of each type of microorganism (24 to 72 hours).

A randomized complete block experimental design was used, with eight treatments and three replications. The data was statistically analysed by the procedures of analysis of variance, according to the SISVAR software (Ferreira, 2000) and the Scott-Knott test was used at $5 \%$ of probability to compare the means between the treatments.

\section{Results and Discussion}

The addition of inoculants did not influence $(\mathrm{P}>0.05)$ the chemical composition of the sugar cane at ensiling. The average DM rate was adequate for ensiling, that is, over $28 \%$ (Table 1 ).

Table 1 - Bromatological composition of sugar cane treated with inoculants before ensiling

\begin{tabular}{lrrrr}
\hline & DM (\%) & CP & NDF & ADF \\
\cline { 3 - 5 } & & \multicolumn{3}{c}{ \% in the DM } \\
\hline Mean values* & 31.2 & 3.1 & 58.9 & 32.0 \\
CV (\%) & 3.7 & 10.9 & 1.6 & 4.3 \\
\hline
\end{tabular}

${ }^{*}$ Mean values of the sugar cane before ensiling with the different inoculants. $\mathrm{CV}=$ coefficient of variation.
Table 2 shows the population of epiphyte microorganisms of untreated sugar cane and sugar canes treated with different inoculants before ensiling. The addition of the inoculants influenced $(\mathrm{P}<0.05)$ the $\mathrm{LAB}$ populations, but had no effect $(\mathrm{P}>0.05)$ on the counts of yeasts and filamentous fungi. The population of bacteria in the forage without inoculant was relatively low (3.63 log cfu/g). According to Bolsen (1995), the LAB are normally found in relatively low numbers in the cultures $(<3.0 \mathrm{log} \mathrm{cfu} / \mathrm{g})$. However the cutting and chopping of the forage release juice from the plant, which can increase the early number of these bacteria at ensiling. Pedroso et al. (2005) also observed the increase in the LAB population of $4.58 \mathrm{log} \mathrm{cfu} / \mathrm{g}$ forage to $7.47 \mathrm{log} \mathrm{cfu} / \mathrm{g}$ on the third day, coinciding with the period of intense acidification of the silage.

The mean increase in the LAB count in the forage with inoculants was $4.2 \log \mathrm{cfu} / \mathrm{g}$, reaching values close to $10^{8} \mathrm{cfu} / \mathrm{g}$ of forage, that, according to McDonald et al. (1991), is a population large enough to keep good competitivey with the other microorganisms of the epiphyte microbiota.

The application of the inoculants influenced the final LAB population in the silages (Figure 1a). The silages with the L. buchneri strain UFLA-72-SIL and Pioneer 11A44TM inoculants presented higher count of these bacteria, followed by the control silage and by the silages with the L. plantarum Biomax $5^{\circledR}$ and L. buchneri SiloMax Lalsil Cana ${ }^{\circledR}$ inoculants. The silages with the $L$. plantarum strain UFLA-1-SIL, L. paracasei strain UFLA-67-SIL and L. brevis strain UFLA-65-SIL inoculants presented the lowest LAB counts. Two of the three inoculated with $L$. buchneri presented higher final LAB count compared with the ones inoculated with the L. paracasei, L. brevis and $L$. plantarum species, that can be related to the

Table 2 - Lactic acid bacteria (LAB), yeasts and filamentous fungi (FILFU) populations in the sugar cane treated with the different inoculants before ensiling

\begin{tabular}{|c|c|c|c|}
\hline \multirow[t]{2}{*}{ Silage ${ }^{1 *}$} & LAB & Yeasts & FILFU \\
\hline & \multicolumn{3}{|c|}{$\log \mathrm{cfu} / \mathrm{g}$} \\
\hline Control, without inoculant & $3.63 b$ & $5.85 a$ & $5.40 \mathrm{a}$ \\
\hline L. plantarum strain UFLA-1-SIL & $8.16 \mathrm{a}$ & $6.30 \mathrm{a}$ & $5.47 \mathrm{a}$ \\
\hline L. paracasei strain UFLA-67-SIL & $8.15 a$ & $6.12 \mathrm{a}$ & $5.45 \mathrm{a}$ \\
\hline L. brevis strain UFLA-65-SIL & $7.63 a$ & $6.16 a$ & $5.40 \mathrm{a}$ \\
\hline L. buchneri strain UFLA-72-SIL & $7.86 a$ & $6.26 \mathrm{a}$ & $5.50 \mathrm{a}$ \\
\hline L. buchneri of the Pioneer 11A44TM inoculant & 7.93a & $6.25 a$ & $5.38 a$ \\
\hline L. plantarum of the Biomax $5^{\circledR}$ inoculant & $7.62 \mathrm{a}$ & $6.08 \mathrm{a}$ & $5.45 a$ \\
\hline L. buchneri of the SiloMax Lalsil Cana ${ }^{\circledR}$ inoculant & $7.90 \mathrm{a}$ & $6.26 \mathrm{a}$ & $5.36 \mathrm{a}$ \\
\hline Average & 7.36 & 6.16 & 5.42 \\
\hline CV (\%) & 2.73 & 2.92 & 2.55 \\
\hline
\end{tabular}

*Bacteria applied at the dose of $10^{5} \mathrm{cfu} / \mathrm{g}$ forage.

a,b Means followed by the same letter in the column do not differ $(\mathrm{P}>0.05)$ by Scott-Knott test.

$\mathrm{CV}=$ coefficient of variation. 
physiologic particularities of the L. buchneri species which is able to metabolize lactic acid to acetic acid and survive in the final moments of the silage fermentation process (Axelsson, 1994).

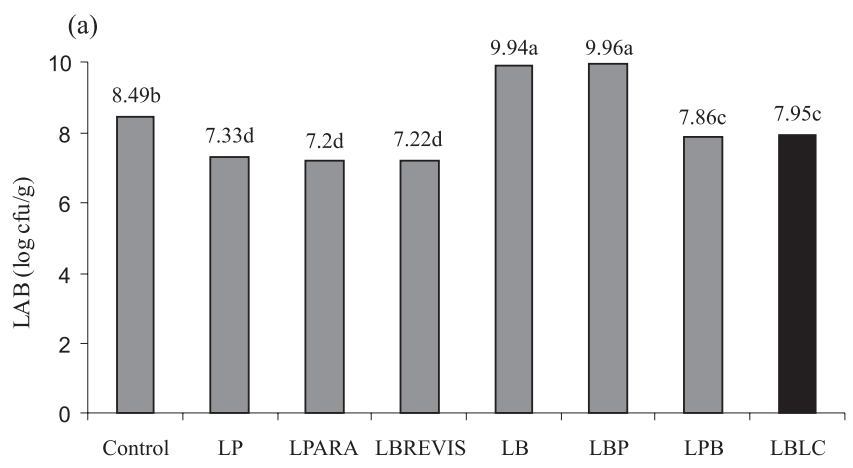

(b)

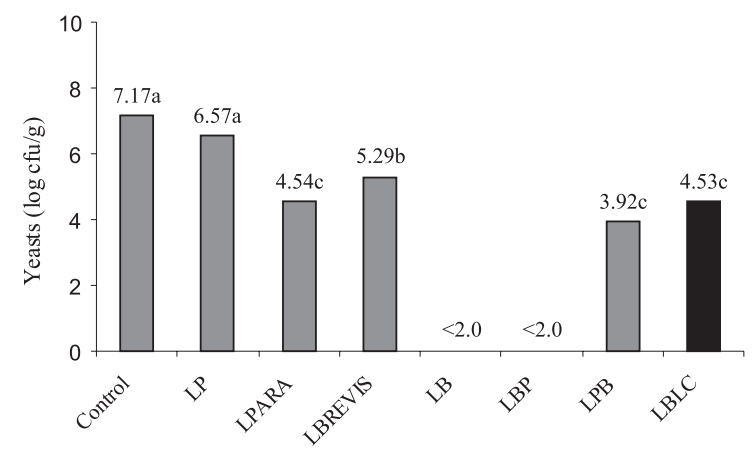

Figure 1 - Counts of lactic acid bacteria (LAB) (a) and yeasts (b) in sugar cane silages treated with inoculants.
In the control silage there was a great increase in the LAB population with the fermentation (8.49 log cfu/g), which is common in silages produced without inoculants. According to Henderson (1993), the population of these bacteria can increase during ensiling, reaching values close to $7 \mathrm{log} \mathrm{cfu} / \mathrm{g}$. Sousa et al. (2008) also observed the high $\mathrm{LAB}$ population at the end of sugar cane fermentation without additives. This increase occurs because, after closing the silo, the conditions of low oxygen concentration and the fall in $\mathrm{pH}$ favor the development of these bacteria, which are microaerophilic and tolerant to acid conditions (Madigan et al., 1997). The average number of the LAB in all the silages (8.19 $\log \mathrm{cfu} / \mathrm{g}$ ) was similar to that reported by Bravo-Martins et al. (2006) for sugar cane silages without inoculants (8.8 log cfu/g).

The yeast population was high in the control silage (Figure 1b). Values between 2.02 and $5.97 \mathrm{log}$ cfu/g silage have been reported for ensiled cane without additives (Bravo-Martins et al., 2006; Bernardes et al., 2007). The inoculant addition influenced the final yeast population in the silages, because the best results were observed in the silages with the L. buchneri strain UFLA-72-SIL and L. buchneri Pioneer 11A44TM inoculants, in which the yeast population was below the minimum detectable level ( $<2 \log \mathrm{cfu} / \mathrm{g}$ ). In the silages where the count was possible, those with the $L$. plantarum Biomax $5^{\circledR}, L$. buchneri Silo Max Lalsil Cana ${ }^{\circledR}$ and L. paracasei strain UFLA-67-SIL inoculants presented the lowest values, followed by the silages with L. brevis strain UFLA-65-SIL.

Table 3 - Lactic, acetic and propionic acids and ethanol contents and the lactic acid:acetic acid ratio in sugar cane silages treated with inoculants

\begin{tabular}{|c|c|c|c|c|c|}
\hline \multirow[t]{2}{*}{ Silage } & Lactic acid & Acetic acid & Lactic:acetic acid & Propionic acid & Ethanol \\
\hline & \multicolumn{5}{|c|}{ (\% in the $\mathrm{DM})$} \\
\hline Control, without inoculant & $1.73 \mathrm{~b}$ & $1.74 \mathrm{c}$ & $1.00 \mathrm{~b}$ & $0.58 \mathrm{c}$ & $6.14 \mathrm{a}$ \\
\hline L. plantarum UFLA-1-SIL strain & $3.02 \mathrm{a}$ & $1.75 c$ & $1.76 \mathrm{a}$ & $0.16 \mathrm{~d}$ & $3.44 b$ \\
\hline L. paracasei UFLA-67-SIL strain & $3.80 \mathrm{a}$ & $1.83 c$ & $2.07 \mathrm{a}$ & $0.17 \mathrm{~d}$ & $3.67 b$ \\
\hline L. brevis UFLA-65-SIL strain & $2.10 \mathrm{a}$ & $4.97 a$ & $0.43 \mathrm{~b}$ & $0.12 \mathrm{~d}$ & $1.15 \mathrm{e}$ \\
\hline L. buchneri UFLA-72-SIL strain & $3.06 \mathrm{a}$ & $4.07 \mathrm{a}$ & $0.75 b$ & $1.34 \mathrm{a}$ & $2.10 \mathrm{~d}$ \\
\hline L. buchneri Pioneer 11A44TM & $3.17 \mathrm{a}$ & $4.30 \mathrm{a}$ & $0.73 b$ & $0.71 \mathrm{~b}$ & $2.85 c$ \\
\hline L. plantarum Biomax $5^{\circledR}$ & $2.58 \mathrm{a}$ & $3.17 \mathrm{~b}$ & $0.79 b$ & $0.16 \mathrm{~d}$ & $2.05 \mathrm{~d}$ \\
\hline L. buchneri SiloMax Lalsil Cana ${ }^{\circledR}$ & $3.03 \mathrm{a}$ & $4.55 \mathrm{a}$ & $0.66 \mathrm{~b}$ & $0.16 \mathrm{~d}$ & $2.15 \mathrm{~d}$ \\
\hline Average & 2.81 & 3.30 & 1.03 & 0.44 & 2.94 \\
\hline $\mathrm{CV} \%$ & 18.9 & 12.6 & 20.9 & 16.3 & 10.9 \\
\hline \multicolumn{6}{|l|}{ Contrasts } \\
\hline Control vs others ${ }^{2}$ & $* *$ & $* *$ & $*$ & $* *$ & $* *$ \\
\hline L. buchneri vs $L$. plantarum ${ }^{3}$ & ns & $* *$ & $* *$ & $* *$ & $*$ \\
\hline L. brevis vs L. buchneri ${ }^{4}$ & $*$ & * & ns & $* *$ & $* *$ \\
\hline L. buchneri SiloMax Lalsil Cana ${ }^{\circledR 5}$ & ns & ns & ns & $* *$ & ns \\
\hline
\end{tabular}

${ }^{*}$ Bacteria applied at the dose of $10^{5} \mathrm{cfu} / \mathrm{g}$ of forage.

a,b Means followed by the same letter in the column do not differ $(\mathrm{P}>0.05)$ by Scott-Knott test.

$\mathrm{CV}=$ coefficient of variation. 
The silages with the $L$. plantarum strain UFLA-1-SIL inoculant and control presented similar and higher counts of yeasts, a fact which can be explained by the low rates of acetic acid in these silages (Table 3). Pedroso et al. (2005) and Freitas et al. (2006) also observed greater yeast growth in sugar cane silages inoculated with $L$. plantarum $\left(1 \times 10^{6} \mathrm{cfu} / \mathrm{g}\right)$, with increase in DM loss and ethanol production. There was yeast inhibition in the silages with the $L$. plantarum Biomax $5^{\circledR}$ inoculant, and with $L$. plantarum. However, the rate of acetic acid was higher than in the silage with the L. plantarum strain isolated from the cane, which confirmed the existence of differences between the strains of the same bacterial species.

In the silages inoculated with $L$. buchneri strain UFLA-72-SIL and L. buchneri Pioneer 11A44TM there was yeast inhibition and acetic acid production was around $4.0 \%$, while in the silages inoculated with homolactic bacteria, with lower production of this acid, a lower level of yeast inhibition was observed. These results reinforced the statement that low $\mathrm{pH}$ values are not able to inhibit yeast growth, but the kind of acid formed. (Moon, 1983). Acetic acid, at a pH lower than its $\mathrm{pK}_{\mathrm{a}}$ (4.73), keeps itself in the nonassociated form, so that the intake of the acid through the membrane (permeable to that acid) of the microorganisms occurs via passive transport. Inside the cell, the $\mathrm{pH}$ is 7.0 (superior to $\mathrm{pK}_{\mathrm{a}}$ of the acid) and the acid is dissociated, releasing the $\mathrm{H}^{+}$ions, whose elimination implies energy spent by the microorganisms, being an active transport process, slowing down the growth and enabling the death of the cell. (McDonald et al., 1991).

The filamentous fungi populations were lower than the detectable minimum in all the silages $(<2 \log \mathrm{cfu} / \mathrm{g})$, which is why they were not represented. According to Strom et al. (2006), the inhibition of fungi growth can occur due to low oxygen concentration of, high lactic and acetic acid concentrations or the bacteriocin produced by LAB present in the silage. Similar values were reported by Bravo-Martins et al. (2006).

The inoculants influenced the mean rates of volatile fatty acids, lactic acid and ethanol in the silages (Table 3). Significant concentrations of butyric acid were not found in any of the silages, indicating that there was no increase in the number of cloristridia. The inoculation increased the lactic acid concentration in the silages, though there was no difference among the inoculants. It was expected that the silages inoculated with homofermentative bacteria would present higher lactic acid concentrations when the silos were opened. However, this was not observed. The highest values of the lactic acid:acetic acid ratio obtained in the silages with the L. plantarum strain UFLA-1-SIL and L. paracasei strain UFLA-67-SIL inoculants occured due to the lower acetic acid concentration in those silages. An explanation for the absence of increase in the lactic acid concentration in the silages inoculated with homolactic bacteria could be the use of acid as substract by yeasts (McDonald, 1991), since these were not eliminated in the silages inoculated with those bacteria.

The lactic acid concentrations in the sugar cane silages have been varied. Values between 1.5 and $4.3 \%$ of this acid in the DM can be found in the literature (Alli et al., 1983; Alcântara et al., 1989; Andrade et al., 2001; Freitas et al., 2006). Pedroso et al. (2007) reported values of 5.2 a 7.6 for sugar cane silages with different additives. Kung Jr. \& Stanley (1982) worked with sugar cane silages collected in different periods of vegetative development and obtained lactic acid rates varying between between 2.82 and $5.65 \%$ in the DM. These authors also reported that the silages with lower lactic acid concentrations presented higher ethanol contents.

The highest acetic acid concentrations (Table 3) were observed in the silages inoculated with L. buchneri and $L$. brevis. These two bacterial species present similar metabolism, that is, they have the capacity to degrade lactic acid using glucose as electron acceptor and producing acetate, 1,2-propanodiol and $\mathrm{CO}_{2}$ (Oude Elferink et al., 2001; Axelsson, 1998). According to the tested contrasts, inoculation with these bacteria increased the final acetic acid concentration of the silages, so that the highest values were observed for the silages inoculated with $L$. brevis compared to those inoculated with $L$. buchneri. In the present study, the acetic acid concentrations in the silages inoculated with heterofermentative bacteria were equal to those found by Freitas et al. (2006), who reported values between 2.6 and $4.5 \%$, that were higher than those reported by Andrade et al. (2001) and Pedroso et al. (2007) who obtained values varying between 0.9 and $2.2 \%$ and of 1.93 to $2.9 \%$ for sugar cane with different additives.

In the silage inoculated with the L. plantarum strain of the Biomax $5{ }^{\circledR}$ inoculant, the acetic acid concentration was lower $(\mathrm{P}<0.05)$ than the one observed in the silages inoculated with heterofermentative strains, but higher than the control and silages inoculated with the $L$. plantarum (UFLA-1-SIL strain) strains and L. paracasei (UFLA-67-SIL strain). The L. plantarum species is classified as a facultative heterofermentative LAB, allowing, therefore, heterolactic fermentation when it uses pentose as substract (Axelsson, 1998).

The relations between the lactic and acetic acids were very variable (Table 3 ), with the values varying from 0.43 to 2.07 in the silages with the heterolactic bacteria 
L. brevis and the homolactic bacteria L. paracasei, respectively. The values found in the literature for sugar cane silage, also vary mainly according to the fermentation time and the use or not of additives. Silva et al. (2008) found lactic acid:acetic acid ratio of 1.47 in sugar cane silages without additives and with 80 days of fermentation and attributed the result to the low production of lactic acid in the silages (2.5\%). Sousa et al. (2008) reported values around 0.25 for the lactic acid:acetic acid ratio in the silages of pure cane and treated with L. buchneri, with no difference between the two silages.

The lactic acid:acetic acid ratio observed in good quality silages is between 2.3 and 4.0 (Kung Jr. \& Shaver, 2001), therefore low acetic acid concentrations, increasing the value of this ratio. Studies prove that acetic acid is not responsible for the reduced intake of the low quality silages and that other factors are involved (Driehuis et al., 1999). On the other hand, this acid contributes to the increase in the aerobic stability resulting from its antifungic action (Courtin \& Spoelstra, 1990; Danner et al., 2003). This is specially important in sugar cane silages, because they present intense fermentation by yeasts. A lower lactic acid:acetic acid ratio can be recommended. In the present study, the highest ratios were observed in the silages inoculated with L. paracasei (2.07) and L. plantarum UFLA-1-SIL strain (1.76) (Table 3) resulting from the low acetic acid production; the lowest ratios were determined for the silages inoculated with heterolactic bacteria, due to the higher acetic acid production. The data available in the literature about the best ratios between lactic and acetic acids are, mainly, for corn silages temperate climate forage plants. For sugar cane silages the best ratio between these acids has not been established to date for its best conservation.

The highest concentrations of propionic acid were observed in the silage with L. buchneri strain UFLA-72-SIL and L. buchneri Pioneer 11A44TM inoculants (Table 3). The highest rate was obtained in the silage inoculated with L. buchneri isolated from sugar cane silage (L. buchneri strain UFLA-72-SIL - 1.34\%), a value considered high in relation to the values reported in the literature (Sousa et al., 2008). In the remaining silages, the propionic acid rates varied from 0.12 to $0.58 \%$ in the DM. Schmidt et al. (2007) found mean values of $0.21 \%$ in sugar cane silages produced with several additives and did not detect differences among the silages. Propionic acid is one of the short chained acids with greatest effect on fungi inhibition (Moon, 1983); its presence is desirable in the silages. Congruently, in this study, the silages with higher rates of propionic acid were also those in which the presence of yeasts (L. buchneri strain UFLA72-SIL e L. buchneri Pioneer 11A44TM) was not detected.
Propionic acid is produced by the metabolism of the propionic acid bacteria, which, however, are sensitive to low pH (Madigan et al., 1997). In sugar cane silages without additives, the $\mathrm{pH}$ decreases very quickly, so that these bacteria shoud be inhibited. The final $\mathrm{pH}$ of the silage with L. buchneri strain UFLA-72-SIL inoculant was low (3.46) (unpublished data). However, it refers only to when the silos were opened (90 days); its reduction rate during the process is unknown. Ávila et al. (2009), evaluated this same strain (L. buchneri strain UFLA-72-SIL) and compared it with a commercial inoculant and observed that, in the silage containing the isolated strain, the fall in the $\mathrm{pH}$ occurred more slowly than in the silages with commercial inoculant and without inoculant. Thus, the possible slower fall in the $\mathrm{pH}$ might have favored the survival of the propionic acid bacteria for a longer time, increasing the acid contents in those silages.

All the tested inoculants reduced the ethanol concentration in the silages compared to the control (Table 3). The silage with the $L$. brevis strain UFLA-65-SIL inoculant presented the lowest ethanol concentration $(1,15 \%)$, followed by the silages with the L. plantarum Biomax $5^{\circledR}$, L. buchneri strain UFLA-72-SIL and L. buchneri SiloMax Lalsil Cana ${ }^{\circledR}$ inoculants, which did not differ (mean 2.10\%). The silage treated with the L. buchneri Pioneer 11A44TM inoculant, which contained a heterofermentative strain, presented higher ethanol concentration (2.85\%) compared to the previously cited strain, but lower than the $L$. plantarum strain UFLA-1-SIL and $L$. paracasei strain UFLA-67-SIL inoculants and to the control silage (6.14\%). With the exception of $L$. buchneri Pioneer 11A44TM, the inoculants containing the heterofermentative strain were more efficient in reducing ethanol production compared to the inoculants containing the homofermentative strain.

The lower ethanol concentrations in the silages inoculated with heterofermentative LAB and in the silage inoculated with the homofermentative strain $L$. plantarum Biomax $5^{\circledR}$ can be related to the higher concentration of acetic or propionic acid in those silages (Table 3), which probably inhibited the yeast growth during fermentation (Figure 1). Danner et al. (2003) evaluated the effect of different compounds on the inhibition of yeast growth in grass silages and concluded that, during the fermentation process, several compounds are produced and that it is difficult to evaluate the potential of each compound in the inhibition of silage deteriorative microorganisms. However, acetic acid has been classified as an efficient inhibitor of yeast growth (Moon, 1983), mainly responsible for ethanol production in sugar cane silages. 
The highest ethanol rate was found in the control silage (6.14\% in the DM) and was lower than those found in the literature (Kung Jr. \& Stanley 1982; Pedroso et al., 2005), which varied from 8 to $17 \%$ in the DM in sugar cane silages without inoculant, resulting in aproximate losses of 30\% in the DM during storage. According to McDonald et al. (1991), the ethanolic fermentation is an efficient process, with the formation of two ethanol molecules and two $\mathrm{CO}_{2}$ molecules for each molecule of consumed glucose, which results in high DM loss. In sugar cane silages, this kind of fermentation is a great problem resulting from the excessive DM loss in the ensiled forage. In the present study, despite the different effects of the inoculants, generally, both homo and heterofermentative strains reduced yeast growth and ethanol production, which might have been caused by the competition between the LAB inoculated with the yeasts. The best results, however, were observed with the heterofermentative strains. The L. buchneri strain UFLA-72-SIL and L. buchneri Pioneer 11A44TM treatments, which contained the L. buchneri species, provided similar results, with greater $L A B$ population and lower yeast count. However, the $L$. brevis strain UFLA-65-SIL isolated from sugar cane resulted in silage with a lower ethanol rate.

\section{Conclusions}

The application of bacterial inoculants improved the microbiological profile and reduced ethanol production in the sugar cane silages. Heterolactic bacteria were more efficient than the homolactic ones, but different strains of the same bacteria species acted differently during the fermentative process, which indicated that the use of inoculants for silages should be evaluated considering the strains, the forage plants to be ensiled and the ensiling conditions.

\section{Acknowledgements}

The authors thank the CNPq and FAPEMIG for the financial support received.

\section{References}

ALCÁNTARA, E.; AGUILERA, A.; ELLIOT, R. et al. Fermentation and utilization by lambs of sugarcane harvested fresh and ensiled with and without NaOH. 4. Ruminal kinetics. Animal Feed Science and Technology, v.23, p.323-331, 1989.

ALLI, I.; FAIRBAIRN, R.; BAKER, B.E. et al. The effects of ammonia on the fermentation of chopped sugarcane. Animal Feed Science and Technology, v.9, p.291-299, 1983.
ANDRADE, J.B.; FERRARI JR., E.; BRAUN, G. Valor nutritivo da silagem de cana-de-açúcar tratada com uréia e acrescida de rolão de milho. Pesquisa Agropecuária Brasileira, v.36, n.9, p.1169-1174, 2001.

ASSOCIATION OF OFFICIAL AGRICULTURAL CHEMISTS - AOAC. Official methods of analyses. 13.ed. Washington, D.C., 1980. 1015p. ASSOCIATION OF OFFICIAL AGRICULTURAL CHEMISTS AOAC. Official methods of analyses. 15.ed. Virginia, 1990. v.1. $648 p$

ÁVILA, C.L.S; PINTO, J.C.; FIGUEIREDO, H.C.P. et al. Effects of an indigenous and a commercial Lactobacillus buchneri strain on quality of sugarcane silage. Grass and Forage Science, v.64, n.4, p.384-394, 2009.

AXELSSON, L. Lactic acid bacteria: classification and physiology. In: SALMINEN, S.; VON WRIGHT, A. (Eds.) Lactic aid bacteria: microbiology and functional aspects. 2.ed. New York: Marcel Dekker, 1998. p.1-72.

BERNARDES, T.F.; REIS, R.A.; SIQUEIRA, G.R. et al. Avaliação da queima e da adição de milho desintegrado com palha e sabugo na ensilagem de cana-de-açúcar. Revista Brasileira de Zootecnia, v.36, n.2, p.269-275, 2007.

BOLSEN, K.K. Silage: basic principles. In: BARNES, R.F.; MILLER, D.A.; NELSON, C.J. (Eds.) Forages. 5.ed. Ames: Iowa State University, 1995. p.163-176.

BRAVO-MARTINS, C.E.C; CARNEIRO, L.; CASTRO-GÓMEZ, R.J. et al. Chemical and microbiological evaluation of ensiled sugar cane with different additives. Brazilian Journal of Microbiology, v.37, p.499-504, 2006

COURTIN, M.G.; SPOELSTRA, S.F. A simulation model of the microbiological and chemical changes accompanying the initial stage of aerobic deterioration of silage. Grass and Forage Science, v.45, p.153-165, 1990.

DANNER, H.; HOLZER, M.; MAYRHUBER, E. et al. Acetic acid increases stability of silage under aerobic conditions. Applied and Environmental Microbiology, v.69, n.1, p.562-567, 2003.

DRIEHUIS, F.; OUDE ELFERINK, S.J.W.H.; SPOELSTRA, S.F. Anaerobic lactic acid degradation during ensilage of whole crop maize inoculated with Lactobacillus buchneri inhibits yeast growth and improves aerobic stability. Journal of Applied Microbiology, v.87, p.583-594, 1999.

FERREIRA, D.A.; GONÇALVES, L.C.; MOLINA, L.R. et al. Características de fermentação da silagem de cana-de-açúcar tratada com uréia, zeólita, inoculante bacteriano e inoculante bacteriano/enzimático. Arquivo Brasileiro de Medicina Veterinária e Zootecnia, v.59, n.2, p.423-433, 2007.

FERREIRA, D.F. Análises estatísticas por meio do SISVAR para windows versão 4.0. In: REUNIÃO ANUAL DA REGIÃO BRASILEIRA DA SOCIEDADE INTERNACIONAL DE BiOMetria, 45., 2000, São Carlos. Anais... São Carlos: UFSCar, 2000. p.225-258.

FILYA, I. The effect of Lactobacillus buchneri, with or without homofermentative lactic acid bacteria, on the fermentation, aerobic stability and ruminal degradability of wheat, sorghum and maize silages. Journal of Applied Microbiology, v.95, n.5, p.1080-1086, 2003.

FREITAS, A.W.P.; PEREIRA, J.C.; ROCHA, F.C. et al. Avaliação da qualidade nutricional da silagem de cana-de-açúcar com aditivos microbianos e enriquecida com resíduo da colheita de soja. Revista Brasileira de Zootecnia, v.35, n.1, p.38-47, 2006.

HAMMES W.P.; HERTEL C. The genera Lactobacillus and Carnobacterium In: DWORKIN, M.; FALKOW, S.; ROSENBERG, E. et al. (Eds.). The Prokaryotes, an evolving electronic resource for the microbiological community. 2.ed. New York: Springer-Verlag, 2003. p.320-403.

HENDERSON, N. Silage additives. Animal Feed Science and Technology, v.45, p.35-56, 1993.

HOLT, J.G.; KRIEG, N.R.; SNEATH, P.H.A. et al. Bergey's manual of determinative bacteriology. 9.ed. Baltimore: Williams \& Wilkins, 1994. 787p. 
KUNG, JR., L.; SHAVER, R. Interpretation and use of silage fermentation analysis reports. Focus on Forage, v.3, n.13, p.1-5, 2001.

KUNG JR., L.; STANLEY, R.W. Effect of stage of maturity on the nutritive value of whole-plant sugarcane preserved as silage. Journal of Animal Science, v.54, p.689-696, 1982.

MACFADDIN, J.F. Biochemical tests for identification of medical Bacteria. Baltimore:Willians \& Wilkins, 1980. 227p.

MADINGAN, M.T.; MARTINKO, J.M.; PARKER, J. Brock_biology of microorganisms. 8.ed. New Jersey: Prentice Hall, 1997. 986p.

McDONALD, P.; HENDERSON, A.R.; HERON, S.J. Biochemistry of silage. 2.ed. Marlow: Chalcombe, 1991. 340p.

MOON, N.J. Inhibition of the growth of acid tolerant yeasts by acetate, lactate and propionate and their synergistic mixtures. Journal of Applied Bacteriology, v.55, p.453-460, 1983.

MUCK, R.E.; KUNG JR., L. Effects of silage additives on ensiling. In: SILAGE: FIELD TO FEEDBUNK. NRAES-99, 1997, Herchey. Proceedings... Herchey: NRAES, 1997. p.187-199.

OUDE ELFERINK, S.J.W.H.; KROONEMAN, J.; GOTTSCHAL, J.A. et al. Anaerobic conversion of lactic acid to acetic acid and 1,2-propanediol by Lactobacillus buchneri. Applied and Environmental Microbiology, v.67, n.1, p.125-132, 2001.

PEDROSO, A.F.; NUSSIO, L.G.; LOURES, D.R.S. et al. Efeito do tratamento com aditivos químicos e inoculantes bacterianos nas perdas e na qualidade de silagens de cana-de-açúcar. Revista Brasileira de Zootecnia, v.36, n.3, p.558-564, 2007.

PEDROSO, A.F.; NUSSIO, L.G.; PAZIANI, S.F. et al. Fermentation and epiphytic microflora dynamics in sugar cane silage. Scientia Agricola, v.62, n.5, p.427-432, 2005.
RANJIT, N.K.; KUNG JR., L. The effect of Lactobacillus buchneri, Lactobacillus plantarum, or a chemical preservative on the fermentation and aerobic stability of corn silage. Journal of Dairy Science, v.83, p.526-535, 2000.

SCHMIDT. P.; MARI, L.J.; NUSSIO. L.G. et al. Aditivos químicos e biológicos na ensilagem de cana-de-açúcar. Composição química das silagens, ingestão, digestibilidade e comportamento ingestivo. Revista Brasileira de Zootecnia, v.36, n.5, p.1666-1675, 2007.

SILVA, D.J. Análise de alimentos: métodos químicos e biológicos. Viçosa, MG: Universidade Federal de Viçosa, 1990. $166 p$.

SILVA, E.J.A.; BORGATTI, L.M.O.; MEYER, P.M. et al. Efeitos do teor de carboidratos solúveis sobre as características da silagem de cana-de-açúcar. Revista Brasileira de Zootecnia, v.37, n.8, p.1375-1382, 2008.

SILVA, S.C. A cana-de-açúcar como alimento volumoso suplementar. In: PEIXOTO, A.M.; MOURA, J.C.; FARIA, V.P. (Eds.). Volumosos para bovinos. Piracicaba: Fundação de Estudos Agrários Luiz de Queiroz, 1993. p.59-74.

SOUSA, D.P.; MATTOS, W.R.S.; NUSSIO, L.G. et al. Efeito de aditivo químico e inoculantes microbianos na fermentação e no controle da produção de álcool em silagens de cana-de-açúcar. Revista Brasileira de Zootecnia, v.37, n.9, p.1564-1572, 2008.

STROM, K.; SJOGREN, J.; BROBERG, A. et al. Lactobacillus plantarum MiLAB 393 produces the antifungal cyclic dipeptides cyclo(L-Phe-L-Pro) and cyclo (L-Phe-trans-4-OH-L-Pro) and 3-Phenyllactic acid. Applied and Environmental Microbiology, v.68, n.9, p.4322-4327, 2002. 